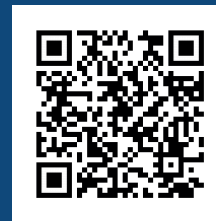

Keywords:

Environment

LAl

Light transmittance

Regeneration

Silviculture

Historic:

Received 28/08/201 8

Accepted 14/12/2018

Correspondence:
Ferhat kara ${ }^{\mathrm{a}+}$, Osman Topaçoğlu'

\section{EFFECTS OF CANOPY STRUCTURE ON GROWTH AND BELOWGROUND/ ABOVEGROUND BIOMASS OF SEEDLINGS IN UNEVEN-AGED TROJAN FIR STANDS}

KARA, F., TOPAÇOĞLU, O. Effects of canopy structure on growth and belowground/ aboveground biomass of seedlings in uneven-aged trojan fir stands. CERNE, v. 24, n. 4, p. 3|2-322, $20 \mid 8$.

\section{HIGHLIGHTS}

The light transmitted through the canopy was the most significant predictor of understory seedlings growth in uneven-aged Trojan fir stands.

Light reaching understory can accelerate the development of sub-canopy layers in unevenaged Trojan fir stands.

Complete canopy closure should be avoided even in stands of shade-tolerant species such as Trojan fir.

\section{ABSTRACT}

Growth and survival of understory seedlings are influenced by their interactions with the environmental variables. The understanding of the relationships between stand density, canopy structure, and understory seedlings' growth help forest managers conduct successful establishment through natural regeneration. In this study, the influence of stand basal area $(B A)\left(m^{2} \cdot h^{-1}\right)$, photosynthetically active radiation transmitted through canopy (PART), leaf area index (LAl), height-to-crown base (HCB) and aspect on the root-collar diameter $(\mathrm{RCD})(\mathrm{mm})$ growth, height growth $(\mathrm{cm})$ and belowground/aboveground biomass $(\mathrm{g})$ of seedlings is observed in uneven-aged Trojan fir stands. Seedling growth and belowground/aboveground biomass models were developed for five growing seasons after germination. PART, aspect and HCB were found to be the most strongly related to RCD and height growth of Trojan fir seedlings. PART and aspect explained the most variance in belowground/aboveground biomass of the seedlings. The data also showed that the light transmitted through the canopy was the most significant predictor of understory seedlings growth; thus, PART reaching understory can accelerate the development of sub-canopy layers in uneven-aged Trojan fir stands. Although survival of Trojan fir seedlings is usually high under canopy, results suggest that complete canopy closure should be avoided even in stands of shade-tolerant species such as Trojan fir to increase a seedling's vigor for its successful recruitment into middle and overstory. The findings of this study will be helpful for forest managers to enhance the establishment and recruitment of Trojan fir seedlings in uneven-aged stands.
' Kastamonu University, Faculty of Forestry. Kastamonu, Turkey. - ORCID: 0000-000 I-7I 07-3176a 


\section{INTRODUCTION}

Successful regeneration of forest stands is usually associated with seedling growth and survival. Growth and mortality of understory seedlings are affected by their interactions with the environmental variables including light, moisture, wind, and temperature (Mason et al., 2004). These variables in a stand could be influenced by stand canopy structure (Aussenac, 2000). High stand density may result in more competition for resources (i.e., moisture and light) and less seedling growth (Uhl et al., 2015). Belowground root biomass is as important as aboveground seedling growth for the successful development of a stand. It influences aboveground growth and carbon cycling (Waring and Powers, 2017), and also plays a critical role in global carbon sequestration (Mobley et al., 2013; Cattanio, 2017). Higher root biomass usually indicates a higher competitive ability for soil nutrients (Lloret et al., 1999; Mokany et al., 2006). Thus, the measurement of root biomass is essential to determine the biochemical processes in an ecosystem (Silver et al., 2005). The interactions among environmental factors and stand canopy structure could impact seedling growth aboveground as well as root biomass belowground (Waring and Powers, 2017).

The lack of knowledge on how overstory affects seedling growth, belowground biomass and seedling recruitment may cause unsuccessful regeneration activities (Lhotka and Loewenstein, 2008). The interactions between canopy structure and seedlings growth are especially important for the successful development of uneven-aged forests where partial cuttings are implemented (Hale, 2003). Trojan fir (Abies nordmanniana subsp.equi-trojani) represents unevenaged stands in Turkey (Odabaşı et al., 2004), and is considered as an important tree species in Turkish forestry providing high quality timber as well as rich biodiversity in the country (Kaya et al., 2008) as well as for determining the genetic similarities between the Abies nordmanniana Spach species complex (A. nordmanniana, A. bornmuelleriana Matff., A. equi-trojani (Asch. \& Sint. ex Boiss. Trojan fir is known to be a shade-tolerant species due to its high survival rate under canopy for a prolonged time (Saraçoğlu, 1988). Consequently, Trojan fir forests have been commonly managed under high stand densities using selection silviculture in Turkey (Odabaşı et al., 2004). However, high survival rate of seedlings under canopy is not the only criteria for successful regeneration and establishment. Growth response of seedling to environmental factors, which is usually associated with stand canopy structure, is also vital. Nevertheless, growth of seedlings in uneven-aged Trojan fir stands have been usually ignored by forest managers in the country. It is possible that disregarding of seedling growth will result in hindered recruitment of seedlings into middle and overstory, which is essential for the sustainability of uneven-aged stands. Therefore, for successful establishment and recruitment of Trojan fir seedlings, the mutual relationships between the stand density, canopy structure and seedling growth must be well understood. Effects of stand density and canopy structure on understory seedlings have been well documented for even-aged stands of shade-intolerant species (Espelta et al., 1995; Brockway and Outcalt, 1998; Pardos et al., 2007; Timilsina and Staudhammer, 2012; Uhl et al., 2015) Quercus ilex (holm oak, as well as uneven-aged stands of shade-tolerant species (Bianchi et al., 2018). However, our knowledge on the factors that influence the above and belowground growth and establishment of Trojan fir seedlings under high stand densities in uneven-aged stands is limited.

The response of seedlings to any silvicultural treatment can be manipulated by forest managers and landowners, as long as the factors that influence seedling growth and survival are well understood (Lhotka and Loewenstein, 2008). Quantitative models and equations through statistical analyses have been commonly used to define the factors that effects seedling growth and tree growth (Hsu et al., 1984; Fang and Bailey, 200I; Pardos et al., 2007; Lhotka and Loewenstein, 2008; Timilsina and Staudhammer, 2012) but most are limited in statistical analysis and biological meaning of indices. Therefore, a mathematical model is proposed to utilize the logistic function. The function was defined as an overall response including time, temperature, and the interaction between time and temperature. Cumulative germination percentages over time were used to develop the model. Germination tests were conducted on indiangrass (Sorghastrum nutans L.). Implementing the knowledge attained from quantitative models and equations may help forest managers develop silvicultural prescriptions that enhance seedling growth in understory (Lhotka and Loewenstein, 2008). The lack of appropriate silvicultural prescriptions on the response of Trojan fir seedlings to canopy structure has resulted in unsuccessful regeneration of these forests in Turkey. Therefore, there is a need to develop quantitative approaches that relate canopy structure to seedling growth and biomass in uneven-aged Trojan fir stands.

To advance the understanding of seedling development in Trojan fir stands, in this study, the 
factors that influence the seedling growth as well as belowground/aboveground biomass were explored. This study considers the variables of stand basal area (BA) $\left(\mathrm{m}^{2} \cdot \mathrm{ha}^{-1}\right)$, photosynthetically active radiation transmitted through canopy (PAR $)$, leaf area index (LAl), height-to-crown base ( $\mathrm{HCB})$, and aspect. BA, which is an absolute measure of stand density, may negatively influence survival and growth of seedlings under canopy. PAR $_{\mathrm{T}}$ which refers to amount of light transmitted through canopy, also affects seedling growth and survival in a stand (Bréda and Granier, 1996). In addition, LAl, which could be associated with $\mathrm{PAR}_{\mathrm{T}}$ is considered an important factor for the analysis of stand structure (Bréda and Granier, 1996). LAl is associated with evapotranspiration, $\mathrm{CO}_{2}$ flows and light interception (Mcwilliam et al., 1993). Moreover, it has been stated that vertical canopy structure (i.e., HCB) could also influence seedling growth and mortality under shade of overstory trees (Lhotka and Loewenstein, 2008). The topographic variable, aspect, has also impact on seedling growth and survival by influencing solar radiation, temperature and soil moisture in a stand (Rosenberg et al., 1983). The main objective of this study was to quantify seedling RCD and height growth, and belowground/aboveground biomass along with BA, PAR, LAI, HCB and aspect in uneven-aged Trojan fir forests. The seedling growth and biomass models presented were developed for five growing seasons after germination.

\section{MATERIAL AND METHODS}

\section{Study site}

This study took place in uneven-aged Trojan fir forests within Kastamonu Regional Directorate of Forestry, Turkey (Figure I). Two uneven-aged Trojan fir stands were selected for the study. The stands chosen were located within the boundary of Samatlar Forest Planning Directorate. One stand with an area of 24.2 ha was chosen on the southern aspect in compartment 89 , while the second stand (22.I ha) was located on the northern aspect in compartment 46. Trojan fir BA constituted more than $90 \%$ of total BA, while Oriental beech (Fagus orientalis) was scattered in some parts of the stands. The stands selected were within the natural distribution range of Trojan fir species (Figure I). The climate represents cold and wet winters $\left(-\mathrm{I}^{\circ} \mathrm{C}\right.$ and $109 \mathrm{~mm}$ of average temperature and precipitation in winter, respectively), while summer is rainy and wet within the region. The average amount of precipitation is $570 \mathrm{~mm}$ per year, while the average annual temperature is $10.9^{\circ} \mathrm{C}$ within the study area. The topography was relatively sloping, ranging from 10 to 30 $\%$ across the study area. Dominant soil types were sandy clay and loamy-clay within the study area. Average altitude was 1350 meter above the sea level. In the understory, blackberry (Rubus spp.) and ferns (Pteridium aquilinum) were present, but they were not dense.

\section{Measurements and analysis}

The study stands have been subjected to singletree selection method for about 60 years, as suggested in their management plan. Within each stand, thirty $100-\mathrm{m}^{2}$ study plots $(10 \times 10 \mathrm{~m})$ were installed (total sixty plots). It should be noted that BA was calculated for plots, while $P A R_{T}, L A I$ and HCB were measured for seedlings. BA of each plot was determined following the diameter at breast height ( $\mathrm{dbh}$ ) measurements of trees larger than $10 \mathrm{~cm}$, and then BA per hectare was calculated for each plot. Three seedlings from the good seed crop year of 2012 were randomly selected and individually tagged within each study plot following the germination period (2013). HCB, which is the vertical distance (m) between the ground and the nearest overhead tree crown (Lhotka and Loewenstein, 2008), was measured using a measurement pole at location of each seedling selected in 2013. PAR measurements were also taken with a $\mathrm{Cl}$-I I0 Plant Canopy Imager (CID Bio-Science Inc., Washington, USA) in the same year. On a nearly cloudless day, preferably between I I:00 am and I:00 pm, a PAR was measured above each seedling selected in understory, and another PAR measurement was taken in an open area. The percentage of PAR transmitted (PAR $\left.{ }_{T}\right)$ through the canopy was calculated using the following formula I for each seedling selected.

$$
\operatorname{PAR}_{\mathrm{T}}(\%)=\left(\left(\frac{(\mathrm{PAR} \text { above seedling })}{(\mathrm{PAR} \text { in the open })}\right)-100\right)
$$

LAl, which is the ratio of total projected leaf area to the projection area of crown, was also measured using the Cl-I IO Plant Canopy Imager (CID Bio-Science Inc., Washington, USA) above each seedling selected (Geiger et al., 20I I). A summary of the stand density and canopy structure variables (i.e., BA, PAR,$L A I$ and $H C B$ ) were presented in Table I.

Following the fifth growing season (2018), the study plots were revisited. As stated above, three seedlings were randomly selected and individually tagged within each study plot in 2013 , and most of them survived five growing seasons. One of these three seedlings was randomly chosen in each study plot (total sixty seedlings) in 2018 . Then, their RCDs were measured using a digital 
TABLE I Descriptive statistics for BA, PAR, LAI and HCB, of the study plots, where $S D$ is the standard deviation of variables $\mathrm{n}$ refers to number of observation.

\begin{tabular}{cccccc}
\hline Variables & $\mathrm{n}$ & Min. & Max. & Mean & SD \\
\hline $\begin{array}{c}\text { BA } \\
\left(\mathrm{m}^{2} \cdot \mathrm{ha}^{-1}\right)\end{array}$ & 60 & 17.2 & 44.76 & 33 & 6.7 \\
$\begin{array}{c}\text { PART } \\
(\%)\end{array}$ & 180 & 0.42 & 35.8 & 12.9 & 8.8 \\
LAl & 180 & 1.17 & 4.66 & 2.7 & 0.6 \\
$\begin{array}{c}\text { HCB } \\
(\mathrm{m})\end{array}$ & 180 & 1.8 & 12 & 5.9 & 2.3 \\
\hline
\end{tabular}

caliper to determine five-year RCD growth. In addition, their heights $(\mathrm{cm})$ were also recorded using a ruler to attain total height growth of seedlings at year five. After the measurements of these seedlings in the field, they were extracted and brought to the laboratory. These extracted seedlings were thoroughly cleaned from soil and other debris, their needles were removed, and they were divided into main stem and root. Root and stem parts were oven-dried for 72 hours at $70^{\circ} \mathrm{C}$ as suggested by Yamashita et al. (2016). Next, they were weighed with a precision balance, and consequently, dry stem and root mass of the seedlings were obtained at age five.

As stated above, the study plots were located in two sites (one of south aspect and one of north aspect). To develop the seedling growth and biomass models, a mixed-effect model incorporating study plots as random effect and nested within the study sites was utilized. Since it was likely that there would be confounding effects among the independent variables (i.e., BA, LAl, $\mathrm{PAR}_{\mathrm{T}}$ and $\mathrm{HCB}$ ), the mixed-effect multiple regression model is recommended (Pourhoseingholi et al., 20I2). The model was defined by the equation below, where $G_{5}$ is the response variable (i.e., five-year RCD growth, height growth, belowground biomass or aboveground biomass), $\beta_{0}$ is the intercept, $R p$ is the random effect for plot, $X^{\top}$ is the transposed matrix of the fixed effects (i.e., BA, PAR, $\mathrm{LAl}, \mathrm{HCB}$ and aspect) and $\varepsilon$ is the error term. It should be noted that BA, PAR, LAI and HCB correspond to the starting point of a given five-year growth period (Lhotka and Loewenstein, 2008). The "Ime" function in R-Statistical software (RDevelopment Core Team, 20 I0) was employed for model fitting. During model fit and variable selection for each model, the variable whose $p$-value was larger than $\alpha=0.05$ was removed from the model, and model was refit after removal of the insignificant variable (Lhotka and Loewenstein, 2008). This process was repeated until the final model included only variables whose $p$-values were smaller than $\alpha=0.05$. Model fits were evaluated based on the coefficient of determination $\left(R^{2}\right)$. $R^{2}$ values of the mixedeffect models were calculated using the "r.squaredGLMM" function in R-Statistical software ( $R$ Development Core Team 2010). The variance inflation factor (VIF) function was used to determine multicollinearity among the selected variables, and there was no multicollinearity issue in the models. Normality and homogeneity of variance were examined through residual analysis.

$\mathrm{G}_{s}=\beta_{0}+\mathrm{Rp}+\mathrm{X}^{\mathrm{T}}+\varepsilon$

\section{RESULTS}

As mentioned above, BA was calculated for each $100-\mathrm{m}^{2}$ plots, while PAR, LAI and HCB were measured above each seedling selected. There was a significant relationship between $B A$ and $\operatorname{PAR}_{T}(p<0.00 I)$, as well as between BA and LAI $(p<0.00 I)$ (Figure 2). Increasing

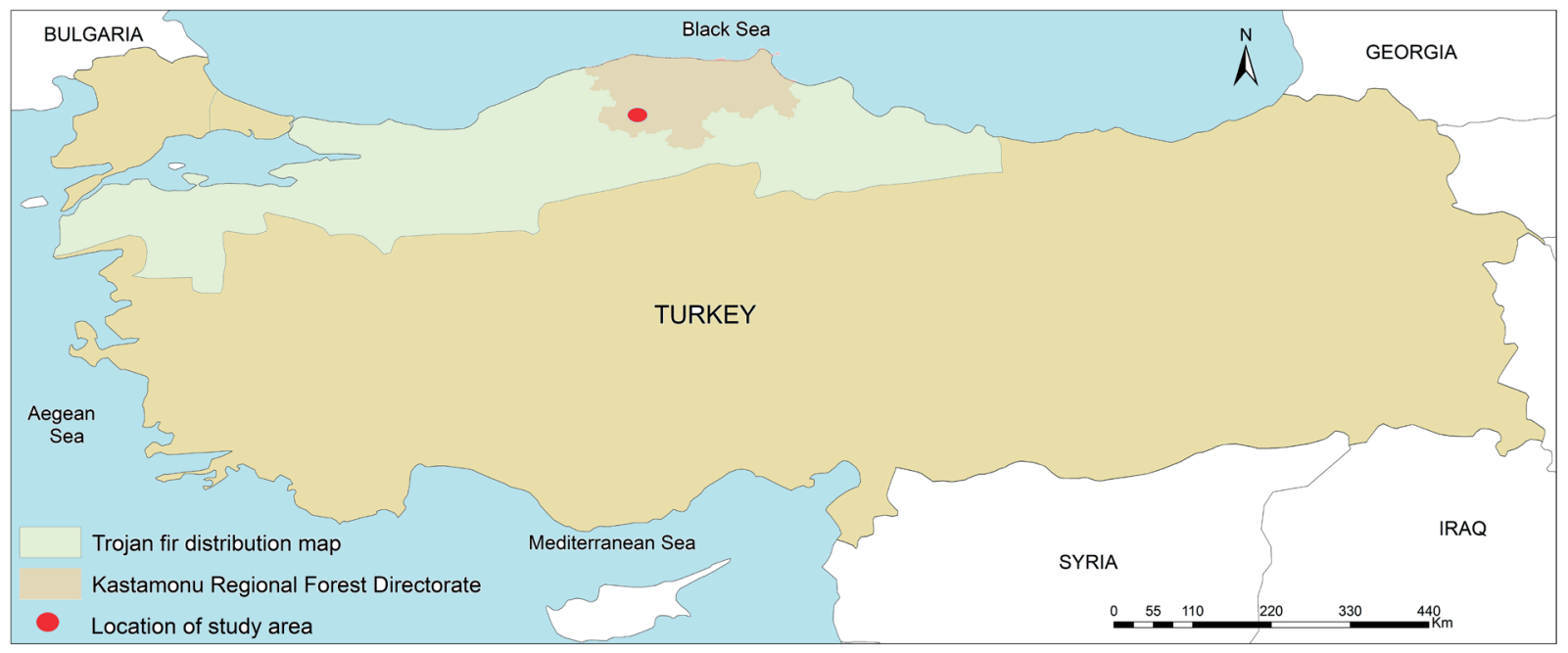

FIGURE I Natural disturbance range of Trojan fir, the boundary of Kastamonu Forest Directorate, and location of study area. 

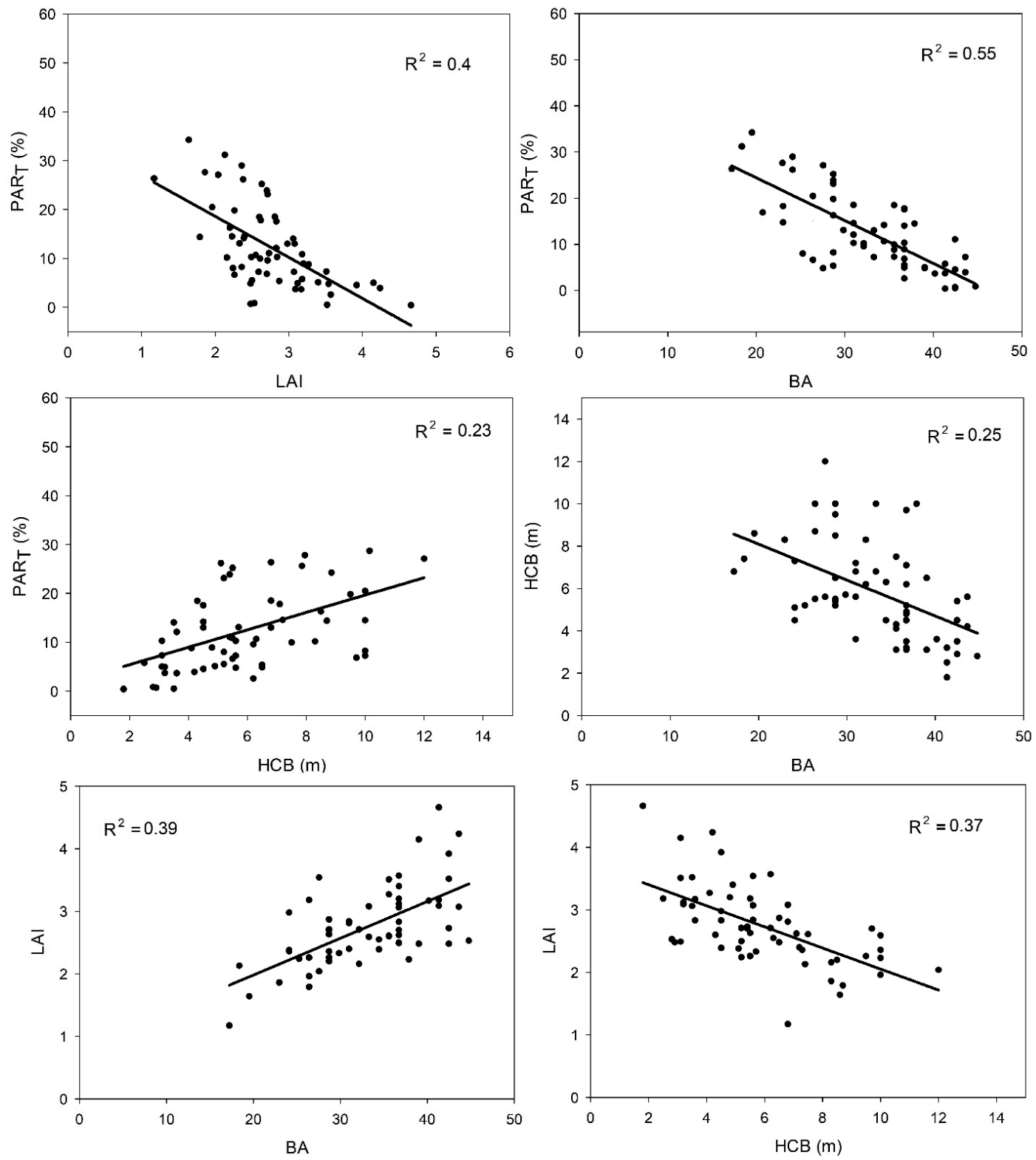

FIGURE 2 Relationships among the independent variables; PART, BA, LAl and HCB.

BA resulted in decreasing amount of $\mathrm{PAR}_{\mathrm{T}}$, and increasing LAI in Trojan fir stands. In addition, statistically significant relationship was observed between $\mathrm{PAR}_{\mathrm{T}}$ and $\mathrm{LAl}$ $(p<0.00 \mathrm{I})$ (Figure 2). The amount of PAR increased with decreasing $L A I$ in uneven-aged Trojan fir stands. Moreover, the positive relationships between $P A R_{T}$ and HCB $(p<0.00 \mathrm{I})$, as well as negative relationship between $\mathrm{LAl}$ and HCB $(p<0.00 I)$ were statistically significant across the study plots (Figure 2). The amount of $P A R_{T}$ increased with increasing $\mathrm{HCB}$, while LAl decreased when $\mathrm{HCB}$ increased (Figure 2). An increase in $\mathrm{BA}$ also resulted in a decreasing HCB across all plots ( $p=0.0264$ ) (Figure 2 ).

The RCD of Trojan fir seedlings ranged from 6.39 to $13.7 \mathrm{~mm}$ with a mean of $9.59 \mathrm{~mm}$ across all seedlings selected, after five growing seasons. The average RCD was 10.09 and $9.08 \mathrm{~mm}$ on the south and north aspect, respectively. In addition, the height of Trojan fir seedlings ranged from 19.8 to $47.1 \mathrm{~cm}$ with an average of $32.2 \mathrm{~cm}$ across all seedlings selected, after five growing seasons. The average seedling height was 35.7 and $28.7 \mathrm{~cm}$ on the south and north aspect, respectively. Moreover, root biomass of Trojan fir seedlings ranged from 2.6 to $23.76 \mathrm{~g}$ with a mean of $12.0 \mathrm{I} g$ across all seedlings selected, after five growing seasons. The average seedling root biomass was 13.45 and $10.57 \mathrm{~g}$ on the south and north aspect, respectively. As for shoot biomass of Trojan fir seedlings, it ranged from 3.91 to $26.5 \mathrm{~g}$ with an average of $13.16 \mathrm{~g}$ across all seedlings selected, after five growing seasons. 
The average shoot biomass was 14.07 and $12.25 \mathrm{~g}$ on the south and north aspect, respectively.

As stated above, the models quantified the relationships between the response variables (i.e., RCD growth, height growth, belowground biomass and aboveground biomass) and the following predictors: $B A, L A I, P A R_{T}, H C B$ and aspect. Not all variables were statistically significant for all models developed at $\alpha=0.05$. Five-year RCD growth model, belowground biomass model and aboveground biomass model all included PAR and aspect as significant predictors $(\alpha=0.05)$ (Table 2). Height growth model utilized the variables $P A R_{,}, H C B$ as well as aspect (Table 2). The models explained 57.9, 76. I, 57.8 and $54 \%$ of the variance for five-year RCD growth, height growth, belowground biomass and aboveground biomass, respectively (Table 2).

It should be noted that south aspect was taken as reference in the mixed-effect model, thus, the negative value of the coefficient of aspect means that north aspect has negative influence on the RCD growth, height growth, belowground biomass and aboveground biomass in uneven-aged Trojan fir stands (Table 2). There was a positive relationship between the height growth of Trojan fir seedlings and HCB; seedling height increases with increasing $\mathrm{HCB}$ (Table 2). PAR showed a positive relationship to five-year RCD growth and height growth; higher RCD and height growth are attained when higher amount of light transmitted through the canopy in uneven-aged Trojan fir stands (Figure 3). Figure 3 also indicated that higher amount of RCD and height growth occur on the south aspect compared to the north aspect in uneven-aged Trojan fir stands.

\section{DISCUSSION}

The relationships between $B A$ and $P A R_{T}$ as well as between LAI and BA, are because an increase in overstory tree density (i.e., BA) likely result in higher crown density (i.e., LAI) and less $\mathrm{PAR}_{\mathrm{T}}$ understory (Espelta et al., 1995). Increasing LAl result in less light transmission through canopy, thus, significant inverse relationships between $\mathrm{PAR}_{\mathrm{T}}$ and LAl is usually observed (Yoder and Waring, 1994). Increasing density of midstory can induce increasing LAI (Yoder and Waring, 1994), and decreasing HCB. Therefore, a significant inverse
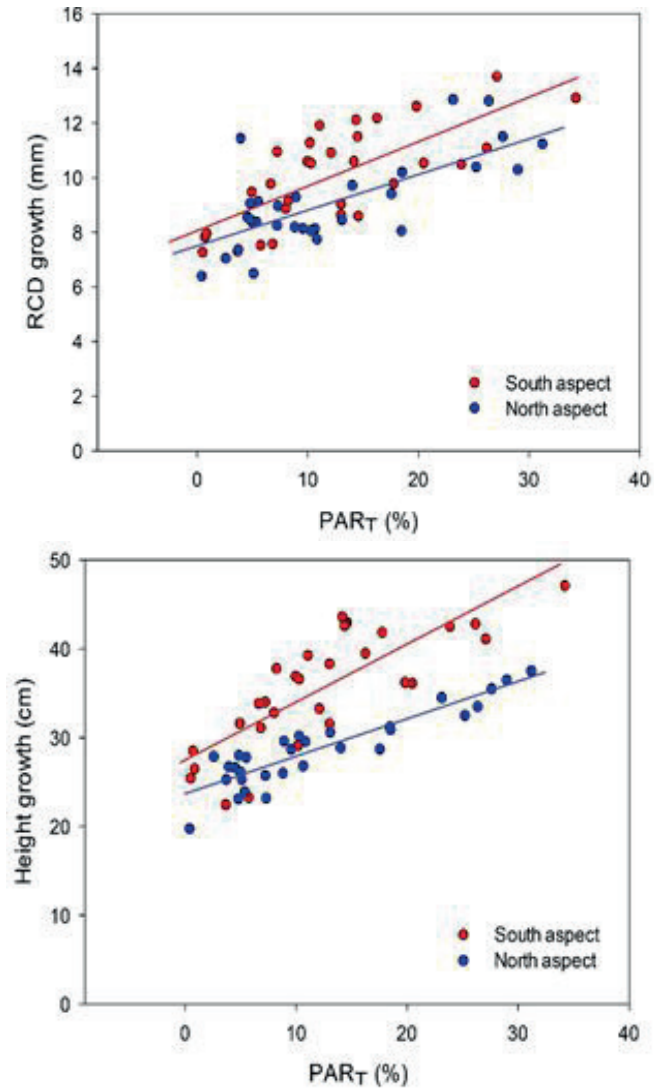

FIGURE 3 Influence of light transmittance through canopy on south and north aspect.

relationship observed between $\mathrm{LAI}$ and $\mathrm{HCB}$ seems to be logical in this study. It is also possible that decreasing HCB will result in higher light transmission through the canopy substantiating the significant relationship between $\mathrm{PAR}_{\mathrm{T}}$ and $\mathrm{HCB}$.

The previous studies revealed that $B A$ negatively influence growth of understory seedlings, while $P A R_{T}$ and HCB positively affect growth of understory seedlings since they all could contribute understory light environment (Espelta et al., 1995; Brockway and Outcalt, 1998; Aussenac, 2000; Collet et al., 200I; Lhotka and Loewenstein, 2008; Kara et al., 2017) a beech stand in which two types of canopy opening (canopy release or gap creation. Stand BA was not statistically significant for the models developed at $\alpha=0.05$. Although BA is commonly used when allocating growing space for

TABLE 2 RCD growth, height growth, aboveground biomass and belowground biomass model coefficients and fit statistics. RCD is the five-year RCD growth $(\mathrm{mm})$, height the five-year height growth ( $\mathrm{cm}), B G B$ is the five-year belowground biomass (g), and AGB is the five-year aboveground biomass $(\mathrm{g})$.

\begin{tabular}{cccccc}
\hline Models & $b_{0}$ & $b_{1}$ & $b_{2}$ & $b_{3}$ & $R^{2}$ \\
\hline$R C D=b_{0}+b_{1} \cdot$ PART $+b_{2}$.Aspect & 8.2534 & 0.1466 & -0.9502 & - & 0.579 \\
Height $=b_{0}+b_{1}$.PART $+b_{2} \cdot H C B+b_{3}$.Aspect & 26.977 & 0.4555 & 0.4656 & -6.2683 & 0.761 \\
$B G B=b_{0}+b_{1} \cdot$ PART $+b_{2}$.Aspect & 9.1447 & 0.3436 & -2.7368 & - & 0.578 \\
$A G B=b_{0}+b_{1} \cdot$ PART $+b_{2}$.Aspect & $8.24 I 1$ & 0.4649 & -1.6256 & - & 0.540 \\
\hline
\end{tabular}


understory seedlings through natural regeneration, some scientists have stated that it is not a good indicator of growing space allocation because growing space at a given BA varies with average tree diameter (Ginrich, 1967; Goelz, 1995; Larsen et al., 2010).

Understanding the linkage between stand canopy structure and understory seedling growth is critical to promote the development of the seedlings in a stand (Lhotka and Loewenstein, 2008). Across the seedling growth and biomass models developed in this study, the variables such as $P A R_{T}, H C B$ and aspect were the significant predictors. It should be noted that BA, HCB, $L A l$ and $P A R_{T}$ measurements were not repeated through time; stand characteristics were measured in 2013 when seedlings were tagged, and seedling growth and biomass were measured at the end of the fifth growing season in 2018. Thus, it is likely that the temporal discrepancy of the stand variables' measurements may exist during the five-year period, and these chances may influence the growth rate of the seedlings. However, we believe that the changes in the stand characteristics during five-year period would not affect the significant relationships of the predictors in the models developed.

Control and alteration of light by forest managers is known to be easier than controlling other environmental factors that affect growth and mortality of understory seedlings. Our results suggest that the amount of light transmitted through the canopy (i.e., $\mathrm{PAR}_{\mathrm{T}}$ ) has high correlation with seedling growth and biomass in Trojan fir forests. With its tolerance to shade, Trojan fir seedlings have high survival rate under overstory canopy for decades (Saraçoğlu 1988). Adequate number of seedlings are usually present in uneven-aged Trojan fir stands in Turkey, but their growth rates have been usually ignored by forest managers. The growth of understory seedlings, however, is essential for the sustainability of unevenaged stands of any species (Grassi et al., 2004; Eerikäinen et al., 2007; Guo and Wang, 2013). Understory fir seedlings can respond to subsequent disturbances, and consequently, grow into middle and overstory (Gray and Spies, 1996; Odabasi et al., 2004). Although Trojan fir seedling is known to be very tolerant to shade, our study indicates the importance of light transmitted through canopy for the seedlings of this species. Accordingly, Gray and Spies (1996) observed the canopy structure effects in Abies amabilis stands, and found lower seedling establishment under closed canopy conditions substantiating the significance of light for shade-tolerant fir species. Moreover, Drever and Lertzman (2003) we estimated gap light or solar radiation reaching the understory through the canopy. Using nonlinear regressions, we related gap light to several structural attributes in the examined silvicultural treatments. The silvicultural treatments affected both the median and range of gap light in the understory. As overstory removal increased from uncut second growth to greentree retention, the median value of light increased from 8 to $68 \%$ full sun, while the range of light increased from $3-22 \%$ to $26-88 \%$ full sun. We found strong, significant, and negative nonlinear relationships between gap light at a particular microsite ( 0.04 ha obtained lower growth and establishment of seedlings under relatively denser canopies following monitoring of the canopy structure effects on understory light environment in Douglasfir (Pseudotsuga menziesii) stands. In a similar study, Madsen (1994) monitored the growth response of Fagus sylvatica, which is also known as a shade-tolerant species, seedlings in relation to light intensity, and concluded that the growth increased with increasing light intensity. Initial data suggest that complete canopy closure should be avoided even in stands of shade-tolerant species such as Trojan fir to increase a seedling's vigor for its successful recruitment into the overstory.

Fir species usually grow slower in their early ages (Hansen and Larsen, 2004). Trojan fir grows relatively faster than other fir species (i.e., A. nordmanniana and A. cilicica) after it is released, in Turkey, demonstrating the importance of light for recruitment of Trojan fir seedlings into the canopy (Kaya et al., 2008) as well as for determining the genetic similarities between the Abies nordmanniana Spach species complex (A. nordmanniana, A. bornmuelleriana Matff., A. equi-trojani (Asch. \& Sint. ex Boiss. Odabasi et al. (2004) stated that average height of Trojan fir seedlings range between 10 and $50 \mathrm{~cm}$ at the end of five growing seasons, depending on understory light conditions. Our average seedling height of Trojan fir seedlings, which ranged from 19.8 to $47.1 \mathrm{~cm}$ at age five (Figure 3), seems to be consistent with previous studies such as Odabasi et al. (2004). Odabasi et al. (2004) pointed out that Trojan fir seedlings' growth are hindered under 10\% light transmitted through canopy, and their annual height growth can reach up to $15 \mathrm{~cm}$ under 50 $60 \%$ of $\mathrm{PAR}_{\mathrm{T}}$ However, our $\mathrm{PAR}_{\mathrm{T}}$ data ranged from 0.4 to $36 \%$ across all plots (Table I), which is relatively lower than it was suggested by Odabasi et al. (2004). Our data suggest that stand density should not be higher than $35 \mathrm{~m}^{2} \cdot \mathrm{ha}^{-1}$ of BA in order to provide at least $10 \%$ light transmission in Trojan fir stands (Figure 2). Therefore, it is likely that density and canopy structure, as well as the intensity and frequency of silvicultural disturbances 
would play a vital role in establishment and recruitment of Trojan fir seedlings into canopy.

This study also examined HCB above the seedlings to observe influence of vertical canopy characteristics on the seedlings, and found that $\mathrm{HCB}$ is an important predictor of seedling height growth. Understory microclimatic conditions can be affected by vertical canopy structure such as HCB (Drever and Lertzman, 2003) we estimated gap light or solar radiation reaching the understory through the canopy. Using nonlinear regressions, we related gap light to several structural attributes in the examined silvicultural treatments. The silvicultural treatments affected both the median and range of gap light in the understory. As overstory removal increased from uncut second growth to greentree retention, the median value of light increased from 8 to $68 \%$ full sun, while the range of light increased from $3-22 \%$ to $26-88 \%$ full sun. We found strong, significant, and negative nonlinear relationships between gap light at a particular microsite (0.04 ha). However, research for the influence of HCB on understory seedlings has been limited (Aussenac, 2000) forest trees and stands have a marked influence on climate; thus it is possible to define microclimates. These effects depend on local climatic characteristics and stand type. All climatic parameters should be considered, but particular attention should be paid to temperature, light and water. From a silvicultural point of view knowledge of the interactions existing between microclimatic conditions and stands, in conjunction with information now available concerning tree ecophysiology make it possible to produce viable applications which are useful for silviculture during stand formation, and for applying silvicultural treat- ments. Whitout a doubt, taking forest cover interactions into account (climate and ecophysiological potential of species), in addition, no such study has been conducted in Trojan fir forests. Our results found out that vertical canopy structure, which was defined as HCB, could affect understory seedling growth. Vales and Bunnell (1988) observed the relationships between stand structure and light transmission, and stated that light transmission increased with decreasing height of crown base (i.e., HCB). In a similar study, Lhotka and Loewenstein (2008) examined the effects of $\mathrm{HCB}$ on the survival and growth of understory seedlings in a mixed deciduous forest, and found that seedling mortality and growth increased with increasing HCB. Our data are consistent with the research that conclude vertical canopy structure affects the understory environment. Therefore, HCB should be taken into consideration during silvicultural treatments in Trojan fir stands as well.

The knowledge on the influence of different slopes on the growth of understory seedlings is of great significance to successful forest management and planning (Hu et al., 20l8). Higher solar radiation and relatively warmer and drier climate on the south-facing slopes may cause reduced tree growth and drought stress (Holland and Steyn, 1975; Måren et al., 2015)both of which are important controls on the growth behaviour, species composition and structure of its vegetation cover. Therefore, information about the radiation environments of topographically diverse areas should provide a basis for predicting the likelihood of local variations in vegetation composition and structure. From a simple model of the annual shortwave energy load of slopes of different angle and compass orientation we predict that aspect effects should be greatest at $45 \mathrm{~N} / \mathrm{S}$ and least in equatorial and polar regions. Other predictions concern likely physiological responses of plants to varying slope angle over the range of latitude. A literature review shows good agreement between these physically based predictions and observations of vegetation patterns in a geographically wide range of countries.An understanding of the differences in vegetation and soil characteristics between slope aspects in high altitude semiarid environments is fundamentally important for efficient management of these semi-natural systems; however, few studies have quantified these differences. Here, we analyzed forest stand characteristics, carbon stocks and soil properties of north- and south-facing slopes in a trans-Himalayan semiarid valley. Pinus wallichiana was the dominant and Juniperus indica the co-dominant species in both aspects, whereas Betula utilis and Abies spectabilis were only recorded in north-facing forests. Pinus regenerated in both aspects, whereas Juniperus did not. Carbon stocks did not differ between aspects; 33t/ha in north-facing and $3 \mathrm{I} / \mathrm{ha}$ in south-facing forests. Similarly, soil properties did not vary between slope aspects, expect for potassium (highest in south-facing slopes. Hu et al. (2018) examined the impacts of slope aspect on forest succession, and they found that the northern aspect provided higher height growth and biomass due to wetter climate and more soil moisture on the northern slopes. In a similar study, Sternberg and Shoshany (200I) monitored the influence of slope aspect on productivity in semiarid and arid sites in Israel, and concluded that the northern aspect presented higher productivity. This can be associated with the soil moisture deficit on the south aspect (Fekedulegn et al., 2003). On the contrary, 
we observed higher seedling growth and biomass on the southern aspect compared to the northern aspect. Lee and Sypolt (1974) soil moisture, radiation exchange, and temperature regimes on adjacent 20 percent northand south-facing slopes suggest that, in areas of high summer precipitation, marked differences in growth are not associated with soil moisture differences. During midday periods on south-facing slopes, it appears that I stated that soil moisture might not be notably variable by aspect in every region. Soil moisture is especially a major driver for growth in relatively drier environments (Sternberg and Shoshany, 200I). Our study region represents wet and rainy conditions throughout the year. Therefore, our findings suggest that light is the main factor for seedling growth in Trojan fir forests, and moisture is not significantly limiting the seedling growth on the northern and southern aspects. It is possible that higher competition for light by understory seedlings was present on the northern aspect, and consequently, lower growth of seedlings was observed.

\section{CONCLUSION}

High survival rate of Trojan fir seedlings has been well documented, but seedling growth has received much less attention in these forests. In this study, the relationships between stand density, canopy structural variables and growth of seedlings were monitored in uneven-aged Trojan fir stands during five growing seasons. We found that light transmitted through the canopy is the most significant predictor of understory seedlings growth. Current data reveals the importance of light transmittance in uneven-aged Trojan fir stands for seedling development and recruitment. Our findings suggest that particular attention should be given to light, even though all climatic and environmental factors play an important role for seedling growth and development. The understanding of the relationships between understory seedlings, canopy structure and environmental factors is the basis of sustainable forest management. Partial canopy openings are not strictly needed for the establishment of shade-tolerant trees species such as Trojan fir. However, our findings suggest that more rapid recruitment of understory seedlings into canopy may occur when providing more light in the understory in Trojan fir forests. Therefore, findings obtained in this study will be helpful for forest managers to enhance the establishment and recruitment of Trojan fir seedlings in uneven-aged stands.

\section{ACKNOWLEDGEMENT}

We thank Samatlar Forest Planning Directorate in Kastamonu, Turkey, for providing us the study area for this research. We also acknowledge Central Research Laboratory (MERLAB) of Kastamonu University for providing us the $\mathrm{Cl}$ - I IO Plant Canopy Imager for this study.

\section{REFERENCES}

AUSSENAC, G. Interactions between forest stands and microclimate: Ecophysiological aspects and consequences for silviculture. Annals of Forest Science. v. 57, p. 28730I, 2000.

BIANCHI, S.; HALE, S.; CAHALAN, C.; ARCANGELI, C.; GIBBONS, J. Light-growth responses of Sitka spruce, Douglas fir and western hemlock regeneration under continuous cover forestry. Forest Ecology and Management. v.422, 24I-252, 2018.

BRÉDA, N.; GRANIER, A. Intra- and interannual variations of transpiration, leaf area index and radial growth of a sessile oak stand (Quercus petraea). Annals of Forest Science. v. 53, 521-536, 1996.

BROCKWAY, D.G.; OUTCALT, K.W. Gap-phase regeneration in longleaf pine wiregrass ecosystems, 1998.

CATTANIO, J.H. Leaf area index and root biomass variation at different secondary forest ages in the eastern Amazon. Forest Ecology and Management. v.400, p. I-I I, 20 I 7.

COLLET, C.; LANTERA, O.; PARDOS, M. Effects of canopy opening on height and diameter growth. Annals of Forest Science. v.58, p. I27-134, 200 I.

DREVER, C.R.; LERTZMAN, K.P. Effects of a wide gradient of retained tree structure on understory light in coastal Douglas-fir forests. Canadian Journal of Forest Research. v.33, p.|37-146, 2003.

EERIKÄINEN, K.; MIINA, J.; VALKONEN, S. Models for the regeneration establishment and the development of established seedlings in uneven-aged, Norway spruce dominated forest stands of southern Finland. Forest Ecology and Management. v. 242, p. 444-46I, 2007.

ESPELTA, J.M.; RIBA, M.; JAVIER, R. Patterns of seedling recruitment in West-Mediterranean Quercus ilex forest influenced by canopy development. Journal of Vegetation Science . v. 6, p. 465-472, 1995.

FANG, Z.; BAILEY, R.L. Nonlinear mixed effects modeling for slash pine dominant height growth following intensive silvicultural treatments, Forest Science. v. 47, n.3, pp. 287-300, 200 I.

FEKEDULEGN, D.; HICKS, R.R.; COLBERT, J.J. Influence of topographic aspect, precipitation and drought on radial growth of four major tree species in an Appalachian watershed. Forest Ecology and Management. v.177, p.409-425, 2003. 
GEIGER, E.L.; GOTSCH, S.G.; DAMASCO, G.; HARIDASAN, M.; FRANCO, A.C.; HOFFMANN, W.A. Distinct roles of savanna and forest tree species in regeneration under fire suppression in a Brazilian savanna. Journal of Vegetation Science. v.22, p.3|2-32।, 201 I.

GINGRICH, S. Measuring and Evaluating Stocking and Stand Density in Upland Hardwood Forests in the Central States . Forest Science. v. 13, p.38-53, 1967.

GOELZ, J.C.G. A Stocking Guide for Southern Hardwoods. Southern Journal of Applied Forestry. v. 19, p. I03-104, 1995.

GRASSI, G., MINOTTA, G., TONON, G., BAGNARESI, $U$. Dynamics of Norway spruce and silver fir natural regeneration in a mixed stand under uneven-aged management. Canadian Journal of Forest Research. v.34, p. |4|-|49, 2004.

GRAY, A.N.; SPIES, T.A. Gap Size, Within-Gap Position and Canopy Structure Effects on Conifer Seedling Establishment. Journal of Ecology. v.84, p.635-645, 1996.

GUO, Q.; WANG, D. Seedling survival and growth under uneven-aged selection silviculture in longleaf pine (Pinus palustris Mill.) ecosystem. Journal of Food Agriculture and Environment. v. II, p.|8|4-|8|9, 2013.

HALE, S.E. The effect of thinning intensity on the below-canopy light environment in a Sitka spruce plantation. Forest Ecology and Management, v. 79, p.34I-349, 2003.

HANSEN, J.K.; LARSEN, J.B. European silver fir (Abies alba Mill.) provenances from Calabria, southern Italy: I5-year results from Danish provenance field trials. European Journal of Forest Research, v.123, p.|27-138, 2004.

HOLLAND, P.G.; STEYN, D.G. Vegetational Responses to Latitudinal Variations in Slope Angle and Aspect. Journal of Biogeography. v.2, p.179-183, 1975.

HSU, F.H.; NELSON, C.J.; CHOW, W.S. A mathematical model to utilize the logistic function in germination and seedling growth. Journal of Experimental Botany, v. 35, p. 1629 1640, 1984.

HU, S.;MA, J.; SHUGART, H.H.; YAN, X. Evaluating the impacts of slope aspect on forest dynamic succession in Northwest China based on FAREAST model. Environmental Research Letters. v. I3, p.I-II, 2018.

KARA, F;; LOEWENSTEIN, E.F; BROCKWAY, D.G. Effects of basal area on survival and growth of longleaf pine when practicing selection silviculture. Forest Systems, v.26, p. I-I2, 2017.

KAYA, Z., SKAGGS, A., NEALE, D.B. Genetic differentiation of Abies equi-trojani (Asch. \& Sint. ex Boiss) Mattf. populations from Kazdağı, Turkey and the genetic relationship between Turkish firs belonging to the Abies nordmanniana Spach complex. Turkish Journal of Botany, v.32, p. I-10, 2008.
LARSEN, D.R.; DEY, D.C.; FAUST, T. A stocking diagram for midwestern eastern cotonwood-silver maple-American sycamore bottomland forests. Northern Journal of Applied Forestry. v.27, p.132-139, 2010.

LEE, R.; SYPOLT, C.R. Toward a Biophysical Evaluation of Forest Site Potential. Forest Science. v.20, p. 145-154, 1974.

LHOTKA, J.M., LOEWENSTEIN, E.F. Influence of canopy structure on the survival and growth of underplanted seedlings. New Forests. v.35, p.89-104, 2008.

LLORET, F; CASANOVAS, C.; PEÑUELAS, J. Seedling survival of Mediterranean shrubland species in relation to root : shoot ratio, seed size and water and nitrogen use. Functional Ecology. v. 13, p.210-216, 1999.

MADSEN, P. Growth and survival of Fagus sylvatica seedlings in relation to light-intensity and soil-water content. Scandinavian Journal of Forest Research. v.9, 316-322, 1994.

MÅREN, I.E.; KARKI, S.; PRAJAPATI, C.; YADAV, R.K.; SHRESTHA, B.B. Facing north or south: Does slope aspect impact forest stand characteristics and soil properties in a semiarid trans-Himalayan valley? Journal of Arid Environments. v. I2I, p.II2-I23, 2015.

MASON, W.L.; EDWARDS, C.; HALE, S.E. Survival and early seedling growth of conifers with different shade tolerance in a Sitka spruce spacing trial and relationship to understorey light climate. Silva Fennica. v.38, p.357-370, 2004.

MCWILLIAM, A.L.C., ROBERTS, J.M., CABRAL, O.M.R., LEITAO, M.V.B.R., DECOSTA, A.C.L., MAITELLI, G.T., ZAMPARONI, C.A.G.P., Leaf-area index and aboveground biomass of terra-firme rain-forest and adjacent clearings in Amazonia. Forest Science. v.7, p.310-317, 1993.

MOBLEY, M.L.; RICHTER, D. DEB.; HEINE, P.R. Accumulation and decay of woody detritus in a humid subtropical secondary pine forest. Canadian Journal of Forest Research. v.43, 109-118, 2013.

MOKANY, K.; RAISON, R.J.; PROKUSHKIN, A.S. Critical analysis of root: Shoot ratios in terrestrial biomes. Global Change Biology. v. I2, p.84-96, 2006.

ODABASI, T.; CALISKAN, A.; BOZKUSS, H.F. Silviculture Technique. Istanbul University Publications. Publication no: 4459. Istanbul, p.3 I4, 2004

PARDOS, M.; MONTES, F.; ARANDA, I.; CAÑELLAS, I. Influence of environmental conditions on germinant survival and diversity of Scots pine (Pinus sylvestris L.) in central Spain. European Journal of Forest Research v. I 26, p.37-47, 2007.

POURHOSEINGHOLI, M.A.; BAGHESTANI, A.R.; VAHEDI, $M$. How to control confounding effects by statistical analysis. Gastroenterology and Hepatology from Bed to Bench, v.5, n.2, p. 79-83, 2012.

ROSENBERG, N.J.; ROSENBERG, N.J.; BLAD, B.L.; VERMA, S.B. Microclimate: the biological environment. John Wiley \& Sons, 1983. 
SILVER, W.L., THOMPSON, A.W., MCGRODDY, M.E., VARNER, R.K., DIAS, J.D., SILVA, H., CRILL, P.M., KELLER, M. Fine root dynamics and trace gas fluxes in two lowland tropical forest soils. Global Change Biology. v. I I, p.290-306, 2005.

STERNBERG, M.; SHOSHANY, M. Influence of slope aspect on Mediterranean woody formations: Comparison of a semiarid and an arid site in Israel. Ecological Research. v. 16, p.335-345, 200I.

TIMILSINA, N., STAUDHAMMER, C.L. Individual Tree Mortality Model for Slash Pine in Florida: A Mixed Modeling Approach. Southern Journal of Applied Forestry. v.36, p.211-219, 2012.

UHL, E.; BIBER, P.; ULBRICHT, M.; HEYM, M.; HORVÁTH, T.; LAKATOS, F.; GÁL, J.; STEINACKER, L.; TONON, G., VENTURA, M., PRETZSCH, H. Analysing the effect of stand density and site conditions on structure and growth of oak species using Nelder trials along an environmental gradient: experimental design, evaluation methods, and results. Forest Ecosystems. v.2, p.I7, 2015.
VALES, D.J.; BUNNELL, F.L. Relationships between transmission of solar radiation and coniferous forest stand characteristics. Agricultural and Forest Meteorology. v. 43, p.20I-223, 1988.

WARING, B.G.; POWERS, J.S. Overlooking what is underground: Root:shoot ratios and coarse root allometric equations for tropical forests. Forest Ecology and Management. v.385, p.10-15, 2017.

YAMASHITA, N., OKUDA, S., SUWA, R., LEI, T.T., TOBITA, H., UTSUGI, H., KAJIMOTO, T. Impact of leaf removal on initial survival and growth of container-grown and bare-root seedlings of Hinoki cypress (Chamaecyparis obtusa). Forest Ecology and Management, p.370, 76-82, 2016.

YODER, B.J., WARING, R.H.The normalized difference vegetation index of small Douglas-fir canopies with varying chlorophyll concentrations. Remote Sensing of Environment. v.49, p.8I-9I, 1994. 